\title{
Biodiversity of Hoverflies (Diptera: Syrphidae) of district Khairpur Mirs, Sindh, Pakistan
}

\author{
Sher Muhammad Kanher ${ }^{*}$, Nasreen Memon ${ }^{1}$ and Syed Mansoor Ali \\ Shah $^{1}$ \\ 1. Department of Zoology, University of Sindh, Jamshoro, Pakistan \\ *Corresponding author's email: kanhersm@gmail.com \\ Citation \\ Sher Muhammad Kanher, Nasreen Memon and Syed Mansoor Ali Shah. Biodiversity of Hoverflies (Diptera: \\ Syrphidae) of district Khairpur Mirs, Sindh, Pakistan. Pure and Applied Biology. Vol. 11, Issue 2, pp404-410. \\ http://dx.doi.org/10.19045/bspab.2022.110040

\begin{tabular}{llll}
\hline \hline Received: 13/01/2021 & Revised: 26/03/2021 & Accepted: 02/04/2021 & Online First: 26/08/2021 \\
\hline
\end{tabular}

\section{Abstract}

Biodiversity of hoverflies was studied from January to December 2016 in six different habitat types present in district Khairpur Mirs. As a result, 688 specimens were collected belonging to 13 species and 8 genera. Simpson and Shannon-Weinner Diversity Indices were used to document species richness and evenness in the habitats like cereal crops, vegetables, fruit farms, oil seed plants,fodder and ornamental plants. In addition to these,Pearson correlation was employed to observe the strength of relationship among hoverflies, host plants and environmental factors. All these species are a new record from this district.

Keywords: Biodiversity; Hoverflies; Khairpur; Species richness and evenness

\section{Introduction}

Hoverflies or flowerflies are very beautiful and useful insects because they perform many functions in an ecosystem. They have medium to large-sized body usually bright coloured and stripped abdomen [1]. They are worldwide distributed and have around 6000 species and are divided in three sub-families i.e. Syrphinae, Eristalinae and Microdontinae [2]. These flies hover around the flowers before landing and are active during day time [3]. Flowerflies are among the most frequent insect visitors to flowers, and pollinate a wide range of plant species [4]. Adult hoverflies use nectar to get energy and pollen for proteins, lipids and vitamins [5]. Some species of this group show excellent mimic of bees or wasps, often with their black and yellow stripes along the abdomen [6]. The larvae of Hoverflies act as natural enemies of multiple insects and exhibit different habits of feeding like aphidophagous, saprophagus, phytophagus and fungivorous [7]. Ecologically, the species of Syrphidae help in pollination, clean the environment as decomposers and assist in bio-control of crop pests. A lot of research study has been carried out in the world on hoverflies. In Pakistan, very little work has been done on these flies particularly by [8-13].

The main purpose of the current study is to document biodiversity of hoverflies present in district Khairpur Mirs as it had been an untouched area of Sindh. To know about distribution, abundance and species richness and evenness of these very important flies from six habitat types (cereal crops, fodder plants, vegetables, oil seeds, ornamental plants and fruit farms) present in different localities of the mentioned district. In the studied sites, interaction of hoverflies with biotic and abiotic factors of ecosystem was observed carefully along with their diversity. Whereas, hoverfly population dynamics due to effect of seasonal variation was also documented by using effective research tools. The present study is of great significance in the sense that all these 13 species are first time reported from this important agricultural region of Sindh, Pakistan.

\section{Materials and Methods}

\section{Study site}

The research was conducted in six plant habitats present in variuos locations of district Khairpur Mirs like Ahmedpur, Gambat, Choondko and Pir-Jo-Goth from January to December 2016. This region of province Sindh occupies an important geographical position where a large variety of crops are grown and it is surrounded by rich agro-ecosystems.It has harsh climatic conditions in the form of extreme Summer and Winter seasons. From May to August, there remains very warm summer season in which temperature reaches up to $50^{\circ} \mathrm{C}$. The GPS (Global Positioning System) was used to measure different Geographical parameters of sampling stations (Table 1). 


\section{Sampling}

The samples were collected time to time every month from four different localities of district Khairpur Mirs. The specimens of Syrphidae were trapped with the help of insect net from cereal crops, vegetables, fruit gardens, oil seed plants, fodder and ornamental plants. During winter, collection was carried out from 10:00 am to 4:00 pm and in summer, collection timing was from 7a.m to $12 \mathrm{p} . \mathrm{m}$ and $5: 00 \mathrm{pm}$ to $6: 30 \mathrm{p} . \mathrm{m}$. After collection with insect hand net, the specimens were put into the jars. Then jars containing hoverflies were kept into the refrigerator for 2-4 hours in order to kill them. These dead flies were put into desiccator containing water mixed with a little quantity of Ethanol for few hours to soften their body parts which can be stretched properly. After stretching of body parts like wings and legs, the specimens were pinned and preserved properly in special wooden insect boxes and labelled as per standard procedure. Some Naphthalene balls were placed at the center and the corners of the boxes in order to repel ants, bacteria and fungi. The information regarding environmental factors, location, host plants and date was provided with each specimen. The specimens were identified under dissecting binocular microscope through related literature and authentic keys like of other researchers [14-18]. Male and female hoverflies were identified and differentiated mainly by the size and shape of their eyes.

Table 1. The GPS showing different geographical parameters of the surveyed localities and habitat types present in district Khairpur Mirs

\begin{tabular}{|c|c|c|c|c|c|}
\hline S No. & Name of locality & Altitude & Latitude & Longitude & Habitat Type \\
\hline 1. & Ahmedpur & $61 \mathrm{~m}$ & $27.55 \mathrm{~N}$ & $68.55 \mathrm{E}$ & $\begin{array}{c}\text { Cereals, fodder crops, oil seeds } \\
\text { ornamental plants and vegetables }\end{array}$ \\
\hline 2. & Gambat & $52 \mathrm{~m}$ & $27.35 \mathrm{~N}$ & $68.52 \mathrm{E}$ & $\begin{array}{c}\text { Cereals, fodder crops, oil seeds and } \\
\text { vegetables }\end{array}$ \\
\hline 3. & Choondko & $49 \mathrm{~m}$ & $27.52 \mathrm{~N}$ & $69.04 \mathrm{E}$ & $\begin{array}{c}\text { Fruit gardens, cereals, fodder crops, oil } \\
\text { seeds and vegetables }\end{array}$ \\
\hline 4. & Pir-Jo-Goth & $53 \mathrm{~m}$ & $27.59 \mathrm{~N}$ & $68.61 \mathrm{E}$ & $\begin{array}{c}\text { Fruit gardens, cereals, fodder crops, oil } \\
\text { seeds, ornamental plants and vegetables }\end{array}$ \\
\hline
\end{tabular}

\section{Data analysis}

\section{Species richness and evenness}

Biodiversity of species increases with the complexity of habitat. It takes in account both the species richness and evenness. Species evenness measures abundance of various species which make the richness of an ecosystem. Therefore, species evenness is a vital part of diversity indices [19, 20].

\section{Simpson diversity index (D)}

It is supposed that the two individuals selected randomly from a sample will be of the same species. This diversity index is more frequently used to observe species richness and evenness. Hoverfly biodiversity of six different habitats present in four localities was measured by using Simpson's Diversity Index(SDI) through following equation:

$$
D=1-\left(\frac{\Sigma n(n-1)}{N(N-1)}\right)
$$

$$
\begin{aligned}
& \mathrm{D}=\text { Simpson Index of Diversity } \\
& \Sigma=\text { sum of total } \\
& \mathrm{n}=\text { the number of individuals of each species } \\
& \mathrm{N}=\text { the total number of individuals of all the } \\
& \text { species }
\end{aligned}
$$$$
\text { The value of } \mathrm{D} \text { is measured from } 0 \text { to } 1
$$

\section{Shannon-Weiner diversity index}

According to Shannon-Weiner Index of Diversity the individuals sampled randomly are from a separate large population and all the species are represented equally in that sample. It is broadly used to compare biodiversity among different habitats [21]. It has following formula:

\section{$\mathbf{H}^{\prime}=-[\Sigma \mathbf{P i} \ln \mathbf{P i}]$}

Where, $\mathrm{H}^{\prime}=$ Diversity Index

$\mathrm{Pi}=$ is the proportion of each species in the sample

$\ln \mathrm{Pi}=$ natural logarithm of this proportion

Shannon Weinner Diversity Index ranges from 1.5 to 3.5 .

To observe the strength and direction of relationship between environmental factors (temperature and humidity) and host plants with hoverflies, Pearson correlation was used and data were analyzed through SPSS 22.0 Software. The value of $r$ (Pearson correlation) ranges from +1 to -1 .

\section{Results and Discussion}

As a result of the present research work, 688 hoverfly specimens belonging to 13 species and 8 genera of two sub-families (Eristalinae and Syrphinae) were collected from six habitats based on 29 plant species in four localities of district Khairpur Mirs throughout the year 2016. These species include; Episyrphus balteatus (Degeer, 1776), Ischiodon scutellaris (Fabricius, 1805) Sphaerophoria scripta (Linnaeus, 1758), Sphaerophoria Indiana (Bigot, 1884), Eupeodes corolla (Fabricius, 1794), Eupeodes luniger (Meigen, 1822), Paragus bicolour (Fabricius, 1794), 
Eristalinus aeneus (Scopoli, 1763), Eristalinus megacephalus (Rossi 1794), Mesembrius bengalensis (Wiedemann, 1819), Mesembrius quadrivittatus (Wiedemann, 1819), Syritta pipiens (Linnaeus, 1758) and Syritta orientalis (Macquart, 1842). The abundance of subfamily Syrphinae (389) was greater than that of sub-family Eristalinae (299). Among the reported species, the maximum population was of Episyrphus balteatus (145) which was observed to visit 20 plant species followed by Eristalinus aeneus (123) having 18 host plants. While the minimum population was of Syritta orientalis (26) which visited 6 plant species. Paragus bicolor had the least number of host plants (5) as shown in (Table 2). The most frequently visited plant species were; Triticum aestvum, Brassica campestris, Mangifera indica, Spinacia oleracea, Coriandrum sotivum and Calendula officinalis.

Table 2. Showing percentage and plant species visited by the hoverflies

\begin{tabular}{|c|c|c|c|c|c|}
\hline 1.Sub-family Syrphinae & $\begin{array}{c}\text { Abundance } \\
\mathbf{( 3 8 9 )}\end{array}$ & $\begin{array}{c}\text { Plant species } \\
\text { visited }\end{array}$ & 2.Sub-family Eristalinae & $\begin{array}{c}\text { Abundance } \\
\mathbf{( 2 9 9 )}\end{array}$ & $\begin{array}{c}\text { Plant } \\
\text { species } \\
\text { visited }\end{array}$ \\
\hline 1.Episyrphus balteatus & $21 \%$ & 20 & 1.Eristalinus aeneus & $17.8 \%$ & 18 \\
\hline 2.Ischiodon scutellaris & $\mathbf{7 . 4} \%$ & 15 & 2.Eristalinus megacephalus & $\mathbf{6 . 5 \%}$ & $\mathbf{1 5}$ \\
\hline 3.Sphaerophoria scripta & $\mathbf{7 . 5 \%}$ & 11 & 3.Mesembrius bengalensis & $\mathbf{5 . 8} \%$ & $\mathbf{7}$ \\
\hline 4.Sphaerophoria indiana & $\mathbf{5 \%}$ & 9 & $\begin{array}{c}\text { 4.Mesembrius } \\
\text { quadrivittatus }\end{array}$ & $\mathbf{4 . 8 \%}$ & $\mathbf{7}$ \\
\hline 5.Eupeodes corollae & $\mathbf{5 . 7 \%}$ & 14 & 5.Syritta pipiens & $\mathbf{4 . 6 \%}$ & $\mathbf{8}$ \\
\hline 6.Eupeodes luniger & $\mathbf{5 . 7 \%}$ & 12 & 6.Syritta orientalis & $\mathbf{3 . 8 \%}$ & $\mathbf{6}$ \\
\hline 7.Paragus bicolor & $\mathbf{4 \%}$ & 5 & & & \\
\hline
\end{tabular}

Among the six habitats from where these hoverflies were collected, cereal crops had the highest Simpson Diversity Index (0.92) and more species richness (13) and the lowest diversity index was of fodder crops (0.88) along with low richness (8). The species evenness was very high in fodder crops (1.08) and the lowest evenness was of cereal crops (1.00). Whereas, the highest Shannon-Weinner Index of diversity was of cereal crops (2.53) and the lowest was of fodder crops (2.05) as given in (Table 3). While, among the four localities, the maximum number of flower flies was collected from Ahmedpur (234) which also had the highest species richness and the minimum abundance was from Gambat (119) having very low species richness.

There was great effect of seasonal variation on the population of hoverflies. During spring season there was much more availability of host plants and season was also favourable for egg laying and feeding of larvae as well as adults. Out of the total collection, 39 percent population was captured in spring which was the highest rate and the lowest 14 percent was caught in winter season (Fig. 1).
It was observed that seasonal variation had great impact on hoverfly catch as mentioned earlier. The maximum population of these flies was captured during spring and the minimum in winter season. Whereas, the largest number of hoverfly individuals was recorded in the month of March (128) and the lowest abundance was observed in January (20) (Fig. 2).

The members of sub-family Syrphinae were more abundant in Spring season than the individuals of sub-family Eristalinae which were in high number during Summer season (Fig. 3).

The pearson correlation revealed that abundance of hoverflies had a strong positive relationship $(\mathrm{r}=0.80, \mathrm{p}=0.002)$ with the number of host plants. Whereas, hoverfly abundance was in weak positive correlation $(\mathrm{r}=0.20, \mathrm{p}=0.5)$ with average temperature. Humidity and hoverfly abundance were found in negative correlation $(\mathrm{r}=-0.38, \mathrm{p}=0.22)$ which indicates if there is high humidity then hoverfly population would be low (Fig. 4, $5 \& 6)$. 
Table 3. Showing different habitats, hoverfly abundance and Diversity Indices

\begin{tabular}{|c|c|c|c|c|c|c|}
\hline $\begin{array}{c}\text { Habitat } \\
\text { type }\end{array}$ & Host plants & $\begin{array}{c}\text { Abundance } \\
\text { of } \\
\text { Hoverflies }\end{array}$ & $\begin{array}{c}\text { Species } \\
\text { Richness } \\
\text { (r) }\end{array}$ & $\begin{array}{l}\text { Species } \\
\text { Evenness } \\
\text { (E) }\end{array}$ & $\begin{array}{l}\text { Simpson } \\
\text { Diversity } \\
\text { Index } \\
\text { (D) }\end{array}$ & $\begin{array}{l}\text { Shannon } \\
\text { Weinner } \\
\text { Diversity } \\
\text { Index }(H)\end{array}$ \\
\hline $\begin{array}{l}\text { Fodder } \\
\text { crops }\end{array}$ & $\begin{array}{c}\text { Alfa alfa (Medicago } \\
\text { sativa), Sorghum (Sorghum } \\
\text { bicolor),Berseem } \\
\text { (Trifolium alexandrinum) } \\
\text { and various types of } \\
\text { grasses. }\end{array}$ & 59 & 8 & 1.08 & 0.88 & 2.05 \\
\hline $\begin{array}{c}\text { Fruit } \\
\text { Farms }\end{array}$ & $\begin{array}{c}\text { Mango(Mangifera } \\
\text { indica),water } \\
\text { melon(Citrullus } \\
\text { lanatus),Muskmelon/Gidro } \\
\text { (Cucumismelo)PhalsaGrewi } \\
\text { a asiatica),Papaya(Carica } \\
\text { papaya). }\end{array}$ & 90 & 11 & 1.07 & 0.91 & 2.39 \\
\hline $\begin{array}{l}\text { Orname } \\
\text { ntal } \\
\text { plants }\end{array}$ & $\begin{array}{l}\text { Marigold(Calendulaofficin } \\
\text { alis), Rose }(\text { Rosa } \\
\text { indica), Yellowbell(Allama } \\
\text { nda),Staticplant } \\
\text { (Limoiumperezii), Daisy }(B e \\
\text { llisperennis),Amarillo } \\
\text { (Tageteserecta). }\end{array}$ & 85 & 9 & 1.06 & 0.89 & 2.18 \\
\hline $\begin{array}{l}\text { Cereal } \\
\text { crops }\end{array}$ & $\begin{array}{c}\text { wheat } \text { (Triticum } \\
\text { aestvum), Rice }(\text { Oryza } \\
\text { sativa), Barely (Hordeum } \\
\text { vulgare) Sorghum } \\
\text { (Sorghum bicolor),Millet } \\
\text { (Pennisetum glaucum). }\end{array}$ & 223 & 13 & 1.00 & 0.92 & 2.53 \\
\hline $\begin{array}{l}\text { Oil seed } \\
\text { crops }\end{array}$ & $\begin{array}{c}\text { Mustard(Brassicacampestri } \\
\text { s),Sunflower (Helianthus } \\
\text { annuus),Janbho(Taramira/a } \\
\text { ngula). }\end{array}$ & 134 & 12 & 1.02 & 0.91 & 2.47 \\
\hline $\begin{array}{l}\text { Vegetabl } \\
\text { es }\end{array}$ & $\begin{array}{c}\text { Toori (Luffaacutangula), } \\
\text { Onion (Allium cepa), } \\
\text { Tomato(Cuminumcyminum, } \\
\text { Ladyfinger } \\
\text { (Abelmoschusesculentus),C } \\
\text { abbge }(\text { Brassicaoleracea }), \mathrm{S} \\
\text { pinach/Palak(Spinaciaolera } \\
\text { cea),Brinjal(Solanummelo } \\
\text { gena),Dhana }(\text { Coriandrums } \\
\text { otivum). }\end{array}$ & 97 & 10 & 1.01 & 0.90 & 2.23 \\
\hline
\end{tabular}

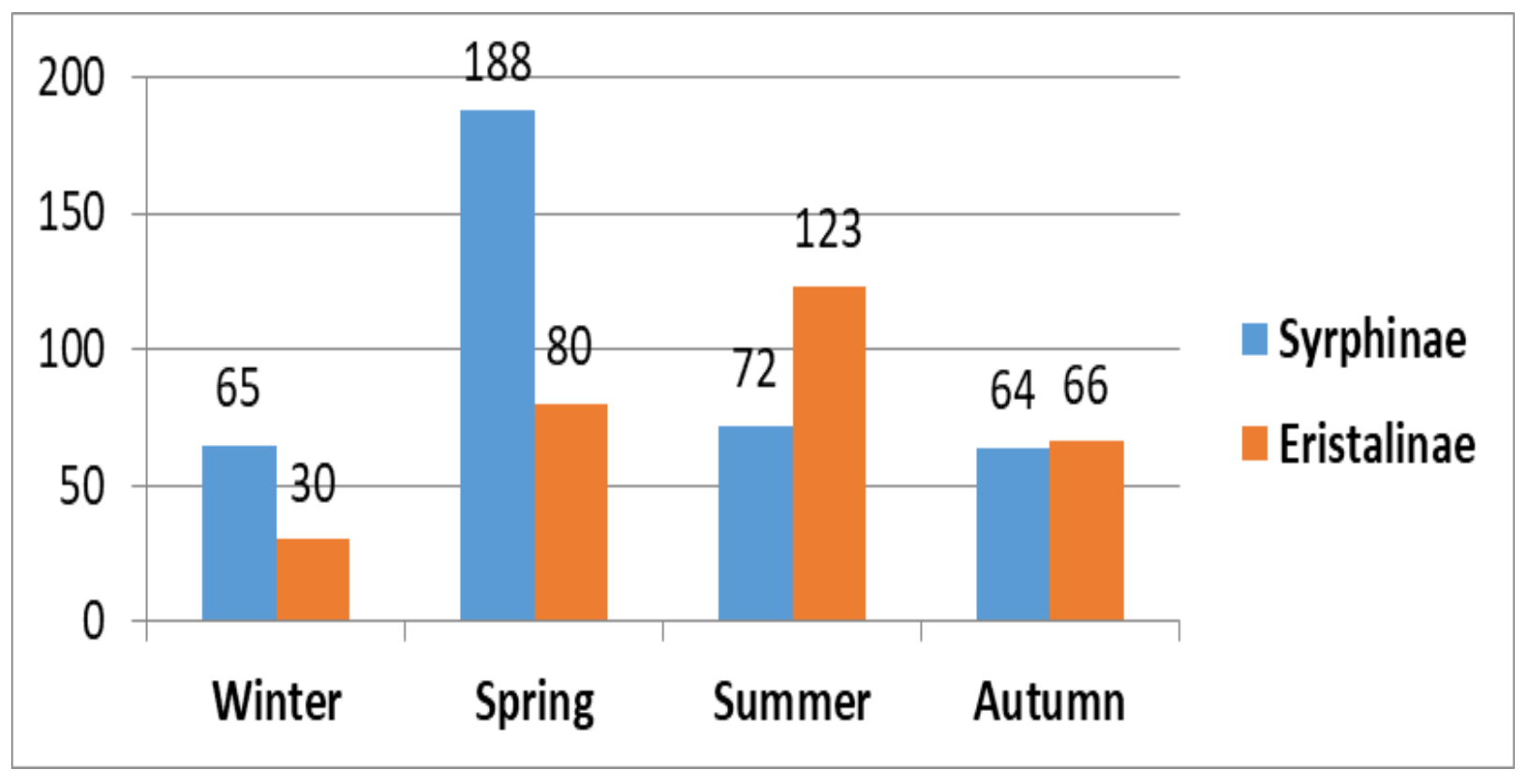

Figure 1. Seasonal variation showing abundance of Syrphinae and Eristalinae during Jan-Dec 2016. 


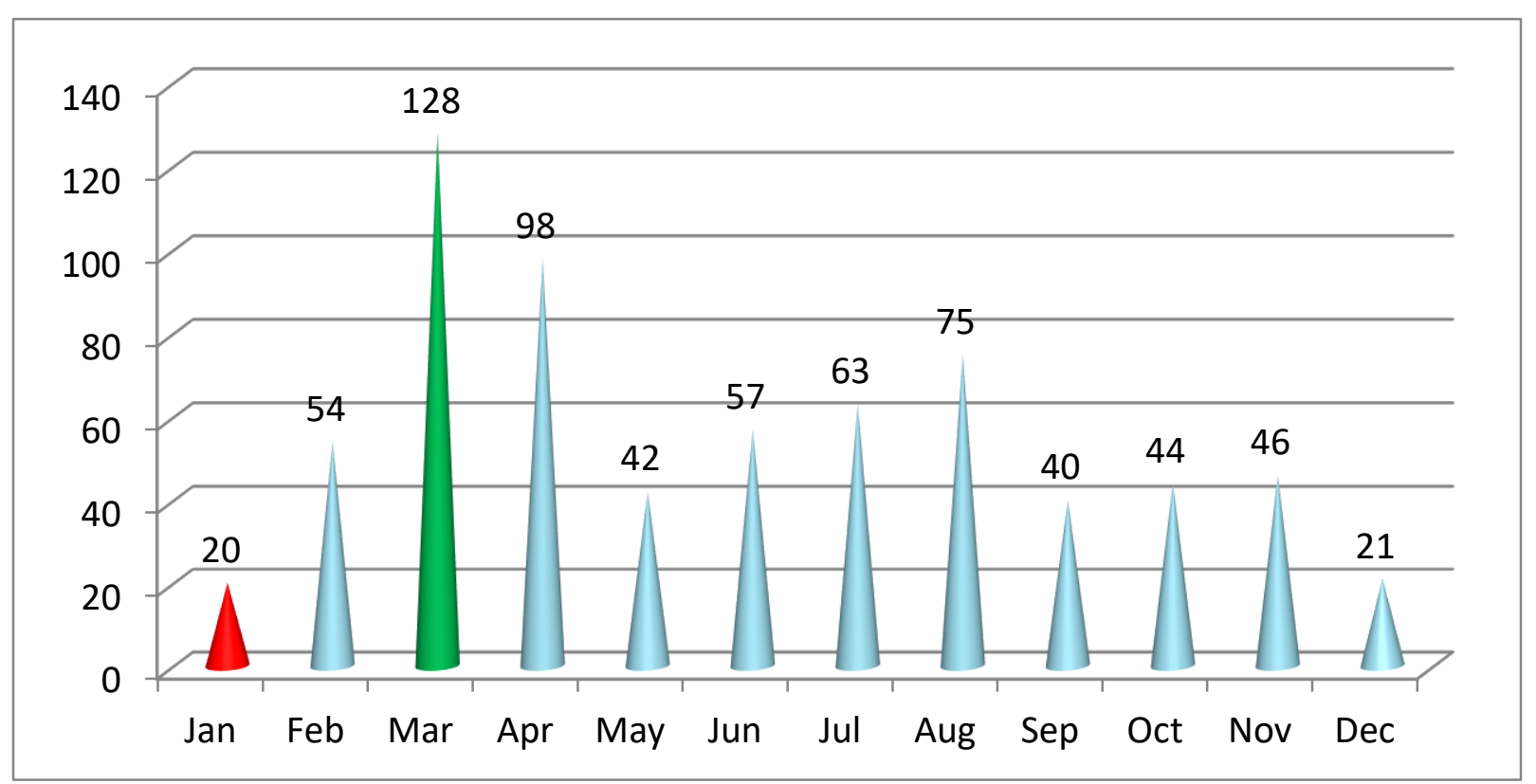

Figure 2. Month wise hoverfly collection from Khairpur Mirs

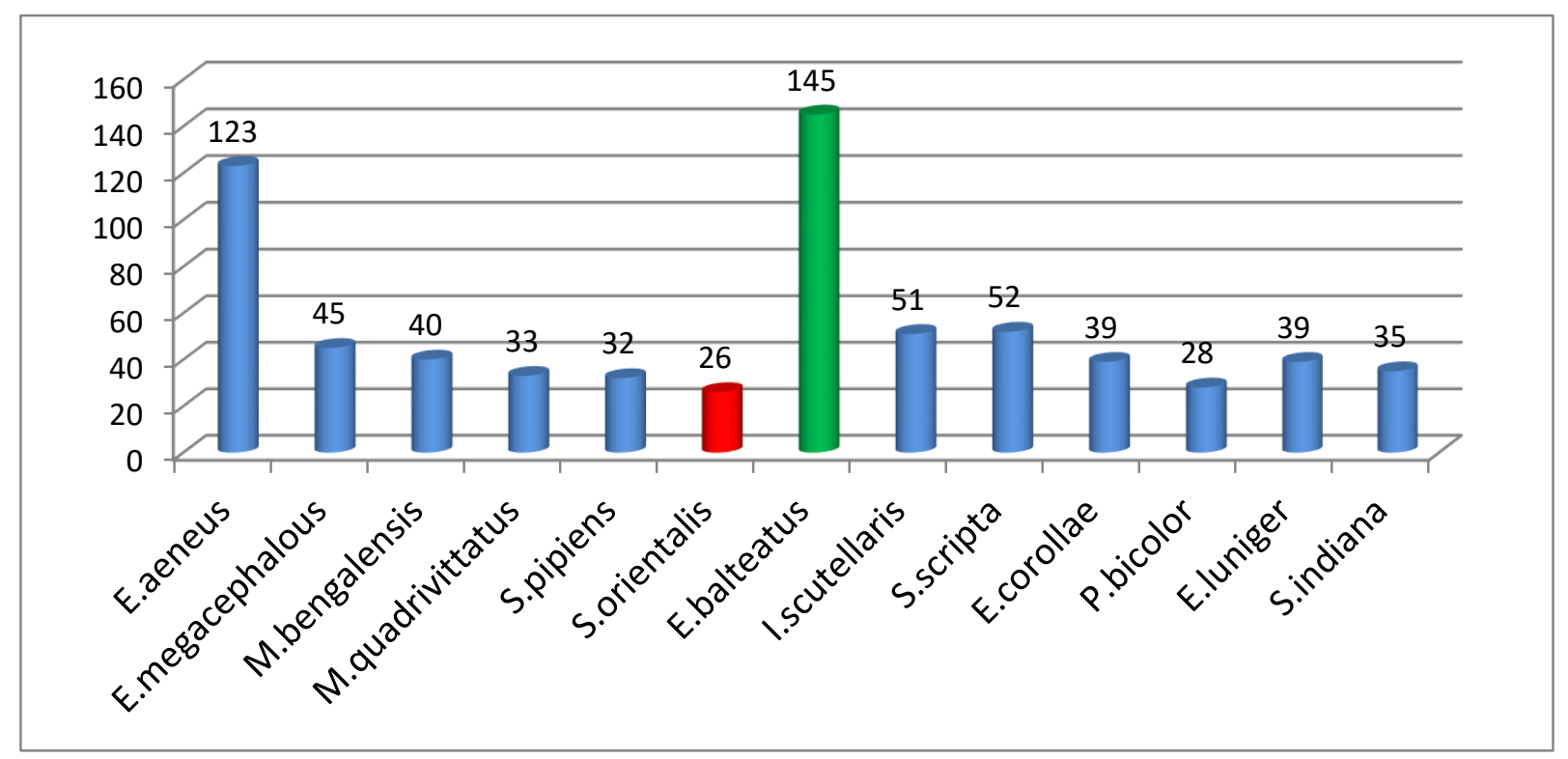

Figure 3. Showing number of different hoverfly species

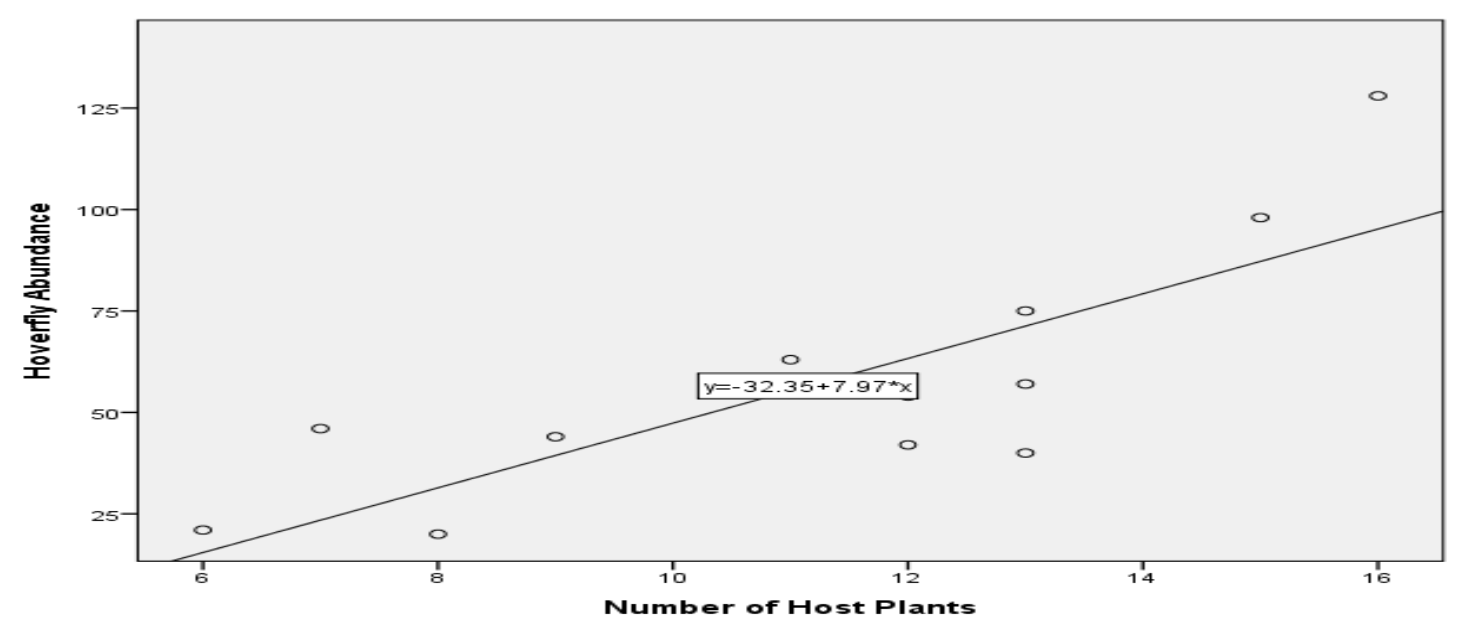

Figure 4. Strong positive correlation between number of host plants and abundance of hoverflies 


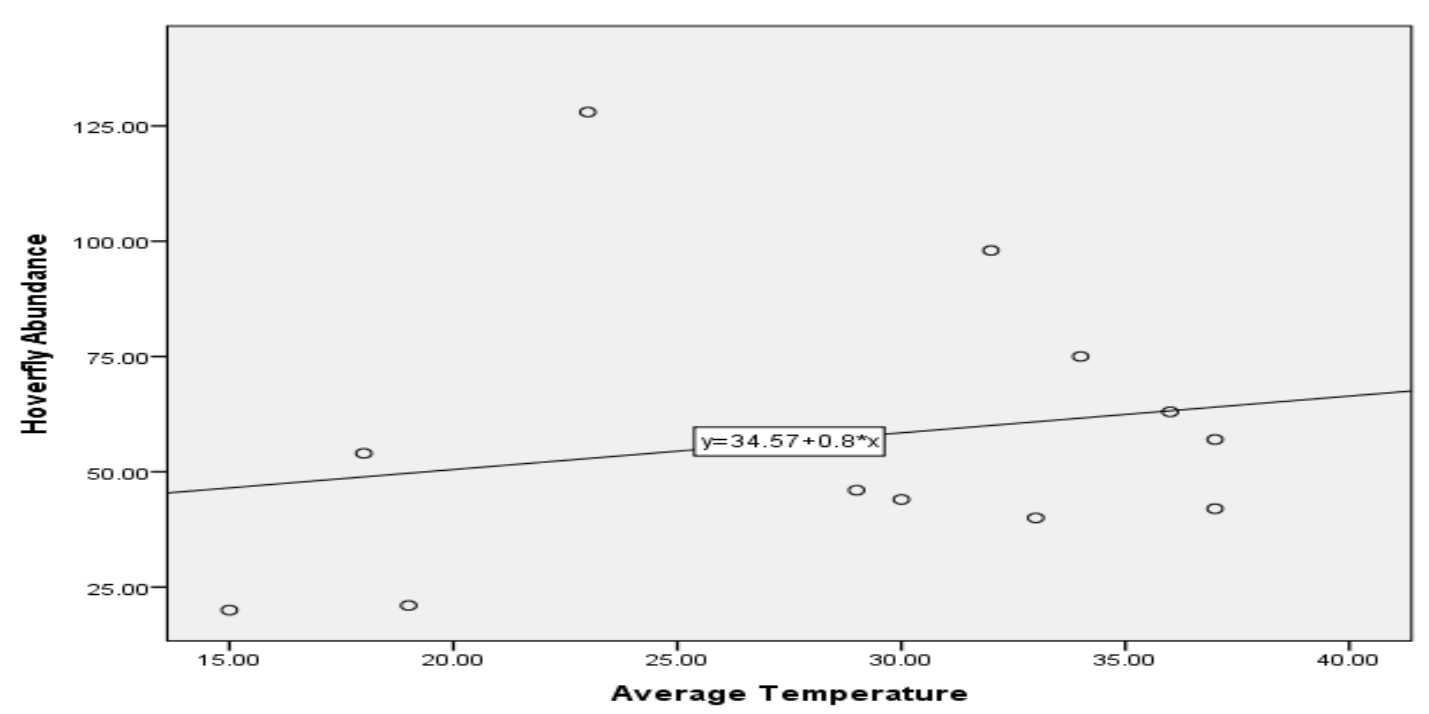

Figure 5. Showing weak positive relationship between average temperature and abundance of hoverflies

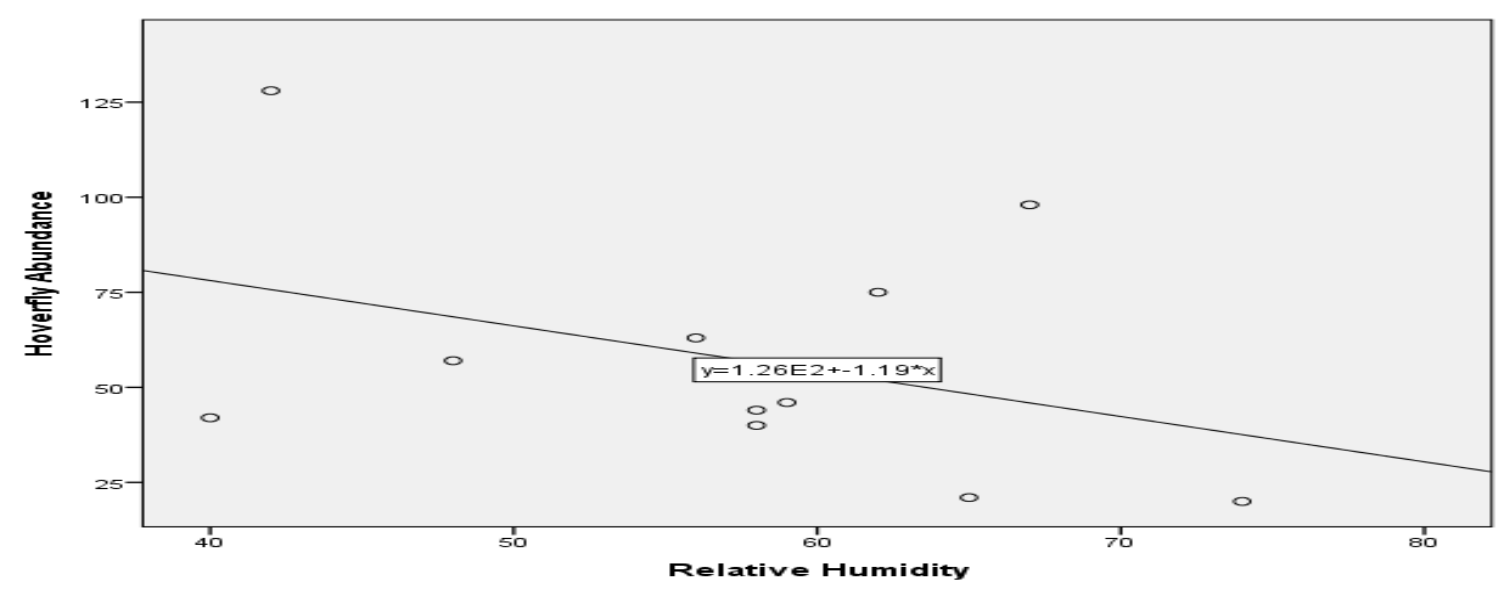

Figure 6. Showing negative relationship between relative humidity and abundance of hoverflies

\section{Discussion}

Hoverflies are widely and abundantly distributed in District Khairpur Mirs and their biodiversity is also rich as indicated by the results. Biodiversity of hoverflies was higher in cereal crops than all the other habitats. The lowest biodiversity of hoverflies was found in fodder crops.Majority of the hoverfly species in this study were aphidophagous. Pearson correlation indicated that there was a strong positive relationship between population of hoverflies and number of host plants which reveals that if there were more host plants then there would be more population of these syrphid flies. In this regard, many earlier researchers have also shown a positive relationship between availability of flowers and pollinators [22-24]. The larvae of subfamily Syrphinae are aphidophagous which play a very important role in biological control of various aphid pests of our crops which seems the main reason behind the highest hoverfly catch from cereal crops like wheat and rice. While, the larvae of Eristalinae are saprophagous. Owing to seasonal variation, syrphid flies thrive throughout the year with fluctuation in their population. The presence of a hoverfly in variable number in a particular habitat greatly depends on the availability of host plants which provide food and shelter for adults as well as larval forms. Species richness and evenness of sub-family Syrphinae was higher than that of sub-family Eristalinae. The members of subfamily Syrphinae were found much sensitive to climatic factors particularly with temperature and their abundance was very low during Summer (i.e. May, June and July in which maximum recorded temperature was $50^{\circ} \mathrm{C}$ in May) and Winter season i.e December to February (temperature ranged from $9^{\circ} \mathrm{C}$ to $16^{\circ} \mathrm{C}$ ) .Whereas, the species of sub-family Eristalinae were observed to bear such a temperature range of upto $50^{\circ} \mathrm{C}$, thatswhy, they remain more active in this season. In Spring and Autumn, Syrphinae remains very active as also reported by Ansari et al. [11].

\section{Conclusion}

It can be concluded from the above discussion that this untouched area of Sindh has rich biodiversity of hoverflies. Their diversity was higher in cereal crops than all 
the other habitats. These flies thrive throughout the year but their population varies with the change of season. Study revealed that majority of the hoverfly species were aphidophagous which means they are useful for the bio- control of the crop pests like aphids. Hence, such eco-friendly flies need attention for natural pest control and enhancement of per acre yield in Sindh as well as in Pakistan.

\section{Authors' contributions}

Conceived and designed the experiments: N Memon \& MA Shah, Performed the experiments: SM Kanher, Analyzed the data: SM Kanher, Contributed materials/ analysis/ tools: SM Kanher, Wrote the paper: SM Kanher.

\section{References}

1. Brunetti E (1923). The fauna of BritishIndia including Ceylon and Burma. Bigot, J.M.F. (1883). Dipteres Nouveaux Ou Peu Connus. Annls Soc Ent Fr 3: 53560.

2. Thompson FC \& Rothray GE (1998). Family Syrphidae -In: PAPP L \& B Darvas (eds), Contributions to a manual of palaeartic Diptera (with special reference to flies of economic importance, 3: 81-139.

3. Kevan PG \& Baker HG (1984). Insects on flowers: pollination and floral visitations. In: Insect Ecology, Eds. CB.

4. Gilbert FS (1981). Foraging ecology of hover flies (Diptera: Syrphidae): morphology of the mouthparts in relation to feeding on nectar and pollen in some common urban species. Ecol Entomol 6: 245-262.

5. Faegri K \& Van Der Pijl L (1979). The principles of pollination ecology, Pergamon Oxford, $3^{\text {rd }}$ ed. pp. 244.

6. Vockeroth JR \& Thompson FC (1987). 52. Syrphidae. In: Mc Alpine, JF (Ed.), Manual of Nearctic Diptera, Research Bran Vol. 2.

7. Sommaggio D (1999). Syrphidae: can they be used as bioindicators. Agric, Ecosys \& Environ 74: 343- 356.

8. Ghorpade K \& Shezad A (2013). An annotated checklist and select bibliography of the hover flies (Diptera:Syrphidae) of Pakistan, Indian subcontinent. Colemania 37: 1-26.

9. Ansari A, Memon N, Shah MA, Amur A \& Mal B (2017). Seasonal variation and diversity of hoverflies fauna (Diptera: Syrphidae) in central Sindh, Pakistan. Sarhad J of Agric 35(7).

10. Turk JK, Memon N, Bhojoo Mal, Memon SA, Shah MA \& Solangi DA (2015). Redescription of two species of Genus
Eupeodes Osten Sacken from Quetta Balochistan, Pakistan. J Anim Plant Sci 25(5): 1329-1334.

11. Sajjad A, Saeed S \& Ashfaq M (2010). Seasonal variation in abundance and composition hoverfly(Diptera:Syrphidae) communities in Multan. PakJ Zool 42(2): 105-111.

12. Saleem M, Arif Mj \& Suhail A (2001). Short communication taxonomic studies of syrphidae of peshawar-pakistan. Int J Agric Biol 3(4): 533-534.

13. Aslam Khan M, Safdar S \& Azizullah (1997) Biodiversity of Syrphidae of Pakistan. Biologia 43(1): 19-25.

14. Stubbs A E \& Falk SJ (2002). British Hover Flies. An Illustrated Identification Guide. Pub. The British Entomology and Natural History Society, Reading, UK. pp. 467.

15. Van veen (2004). Hoverflies of Northwest Europe, Identification Keys to the Syrphidae, KNNV Publishing, Utrecht, The Netherlands.

16. Speight MCD (2011). Species accounts of European Syrphidae (Diptera). 65: 285.

17. De-Groot \& Govedic M (2008). Checklist of the hoverflies (Diptera: Syrphidae) of Slovenia. Acta Entomologica Slovenica 16(1): 67.

18. Ghorpadé K (2015). Hover-flies (Diptera-Syrphidae) documented from the Northwest Frontier of the Indian Subcontinent: A circumstantial history and inclusive bibliography. Colemania 50: 1151.

19. Hill MO (1973). Diversity and evenness: a unifying notation and its consequences. Ecol 54: 427-432.

20. Leinster T \& Cobbold CA (2012). Measuring diversity: the importance of species similarity. Ecol 93(3): 477-489.

21. Clarke KR \& Warwick RM (2001). Change in marine communities: an approach to statistical analysis and interpretation. $2^{\text {nd }}$ edition, primer-e Ltd, Marine Laboratory Plymouth.

22. Wolda AH (1988). Seasonality and the community. pp. 69-95. In: Organization of communities: Past and present (eds JHR Gee and PS Giller). Blackwell. Oxford, pp. 365.

23. Inouye \& Kearns (1993). Techniques for Pollination Biologists, University Press of Colorado.

24. Souza-Silva M, Fontenelle JCR \& Martins RP (2001). Seasonoal abundance and species compositon of flower-visiting flies. Neotrop Ent 30: 351359. 